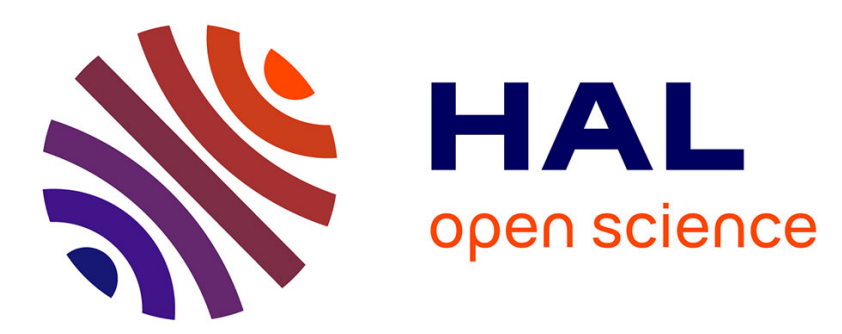

\title{
Responses of labile soil organic carbon and enzyme activity in mineral soils to forest conversion in the subtropics
}

\author{
Qingkui Wang, Fuming Xiao, Tongxin He, Silong Wang
}

\section{To cite this version:}

Qingkui Wang, Fuming Xiao, Tongxin He, Silong Wang. Responses of labile soil organic carbon and enzyme activity in mineral soils to forest conversion in the subtropics. Annals of Forest Science, 2013, 70 (6), pp.579-587. 10.1007/s13595-013-0294-8 . hal-01201499

\section{HAL Id: hal-01201499 \\ https://hal.science/hal-01201499}

Submitted on 17 Sep 2015

HAL is a multi-disciplinary open access archive for the deposit and dissemination of scientific research documents, whether they are published or not. The documents may come from teaching and research institutions in France or abroad, or from public or private research centers.
L'archive ouverte pluridisciplinaire HAL, est destinée au dépôt et à la diffusion de documents scientifiques de niveau recherche, publiés ou non, émanant des établissements d'enseignement et de recherche français ou étrangers, des laboratoires publics ou privés. 


\title{
Responses of labile soil organic carbon and enzyme activity in mineral soils to forest conversion in the subtropics
}

\author{
Qingkui Wang • Fuming Xiao • Tongxin He • Silong Wang
}

Received: 1 December 2012 / Accepted: 30 April 2013 /Published online: 16 May 2013

(C) INRA and Springer-Verlag France 2013

\begin{abstract}
- Aims Globally, extensive areas of native forest have been almost replaced by plantations to meet the demands for timber, fuel material and other forest products. This study aimed to evaluate the effects of forest conversion on labile soil organic C (SOC), soil respiration, and enzyme activity, and to quantify their relationship in subtropical forest ecosystems.

- Methods Surface mineral soil $(0-20 \mathrm{~cm})$ was collected from a Cunninghamia lanceolata Hook. plantation, Pinus massoniana Lamb. plantation, Michelia macclurei Dandy plantation, and an undisturbed native broadleaf forest. Soil microbial biomass $\mathrm{C}$, dissolved organic $\mathrm{C}$, permanganateoxidizable $\mathrm{C}$, basal respiration, and six enzyme activities were investigated.

- Results Soil microbial biomass C was higher by $45.9 \%$ in native broadleaf forest than that in M. macclurei Dandy plantation. The ratio of soil microbial biomass $\mathrm{C}$ to total SOC was $27.6 \%$ higher in the M. macclurei Dandy plantation than in the native broadleaf forest. The soil respiration increased by $25.2 \%$ and $21.7 \%$ after conversion from native broadleaf forest to $P$. massoniana Lamb. and $M$. macclurei Dandy plantations respectively. The effects of
\end{abstract}

\section{Handling Editor: Gilbert Aussenac}

\section{Q. Wang $(\varangle) \cdot$ T. $\mathrm{He} \cdot \mathrm{S}$. Wang}

Huitong Experimental Station of Forest Ecology,

State Key Laboratory of Forest and Soil Ecology,

Institute of Applied Ecology, Chinese Academy of Sciences,

Shenyang 110164, People's Republic of China

e-mail: wqkui@163.com

\section{F. Xiao}

Jiangxi Academy of Forestry, Nanchang 330032,

People's Republic of China

\section{T. He}

University of Chinese Academy of Sciences, Beijing 100039,

People's Republic of China forest conversion on the soil enzyme activities differed among the tree species. Soil microbial biomass $\mathrm{C}$ had higher correlation with soil respiration than with the other SOC fractions. Moreover, soil microbial biomass $\mathrm{C}$ was positively correlated with urease and negatively correlated with cellulase activity. Soil respiration had higher correlation with soil microbial biomass $\mathrm{C}$, dissolved organic $\mathrm{C}$ and permanganate-oxidizable $\mathrm{C}$.

- Conclusion Forest conversion affected the soil microbial biomass $\mathrm{C}$, soil respiration, invertase, cellulase, urease, catalase, acid phosphatase, and polyphenol oxidase activities, but their response depended on tree species. Soil respiration was mainly controlled by labile SOC, not by total SOC.

Keywords Land-use change $\cdot$ Tree species $\cdot$ Labile soil organic C $\cdot$ Soil respiration $\cdot$ Soil enzyme

\section{Introduction}

Globally, plantations with short rotation and high productivity are widely established to meet the demand for timber, fuel material, and other forest products. In 2010, the total area of plantations was approximately 264 million ha, corresponding to $6.6 \%$ of the forest area (FAO 2010). Most plantations were derived from native forests. The conversion of a native forest into a plantation affects the forest ecological processes and functions (Schroth et al. 2002). In past decades, most studies focused on the effects of forest conversion on soil properties such as total soil organic $\mathrm{C}$ (SOC) and other physicochemical properties (Schroth et al. 2002). The simultaneous examination of the changes in labile SOC and soil biological properties induced by forest conversion is important beyond the insights it gives into the effects of forest conversion on the $\mathrm{C}$ cycle, because both labile SOC and soil microbe contribute to the soil $\mathrm{CO}_{2}$ emission, which results in the loss of stored $\mathrm{C}$ in forest soils. 
However, few studies have focused on the simultaneous response of labile SOC and soil biological properties to forest conversion.

Total SOC is heterogeneous, and consists of different functional and biological pools with different turnover rates (von Lützow et al. 2007). Based on turnover rates and residence time, the SOC can be divided into a labile $\mathrm{C}$ pool, which exists for weeks to years, and a recalcitrant $\mathrm{C}$ pool, which exists for decades or even centuries (Rovira and Vallejo 2002). The labile C pool mainly consists of simple sugars, organic acids, microbial biomass, and metabolic compounds of incorporated plant residues, given its rapid turnover (Cochran et al. 2007). Labile SOC fractions include soil microbial biomass $\mathrm{C}$ (MBC), dissolved organic $\mathrm{C}$ (DOC), and permanganate-oxidizable $\mathrm{C}$ (POC). Although the labile fraction is more sensitive to short-term vegetation or land-use change (Sicardi et al. 2004; von Lützow et al. 2007), measuring labile SOC is more laborious and costly than measuring total SOC. However, whether labile SOC is still more sensitive than total SOC on a long-term scale (e.g., 30 years) after forest conversion is unknown.

Soil respiration as a key ecosystem process that releases $\mathrm{C}$ as $\mathrm{CO}_{2}$ from soil is affected by forest conversion. Some studies have shown that the conversion of a natural forest into a plantation leads to a net accretion of soil respiration (Liu et al. 2011). By contrast, Mohanty and Panda (2011) noted that natural forest conversion reduces soil respiration, and $\mathrm{Xu}$ et al. (2008) reported that forest conversion has no effect. The inconsistency in the effect of forest conversion on soil respiration limits our understanding of the forest role in $\mathrm{C}$ cycle. Therefore, the effects of forest conversion on soil respiration must still be quantified. Based on small-scale experiments with similar soil temperature and moisture conditions, soil $\mathrm{C}$ availability is important for soil respiration. Although $\mathrm{C}$ availability affects soil respiration (Dube et al. 2009; Iqbal et al. 2010), the relationship between soil respiration and labile SOC fractions is still poorly understood.

Soil enzymes produced by microbes play key roles in the biochemical functions of organic matter decomposition and nutrient cycling (Waldrop et al. 2004). Soil enzyme activities, which represent microbial activity, are affected by landuse and vegetation changes (Sicardi et al. 2004; AcostaMartínez et al. 2007; Weand et al. 2010). However, some enzyme activities do not consistently respond to forest vegetation changes (Chang et al. 2011). Therefore, a better understanding of the effects of forest conversion on soil enzyme activity, and the relationship between soil enzyme activity and labile SOC, potentially provides an opportunity to assess the response of the soil biogeochemical cycle to land-use change. However, the relationship between different SOC fractions and enzymes is still not clear.

In this study, we investigated the enzyme activities known to play key roles in the mineralization of $\mathrm{C}, \mathrm{N}$, and
P nutrients in soils (Dilly and Nannipieri 2001; AcostaMartínez et al. 2007). For example, acid phosphatase and urease are important in soil $\mathrm{P}$ and $\mathrm{N}$ mineralization because they catalyze the hydrolysis of various organic $\mathrm{P}$ and $\mathrm{N}$ respectively (Acosta-Martínez et al. 2007). Catalase catalyzes hydrogen peroxide decomposition (Brzezińska et al. 2005). Polyphenol oxidase is involved in lignin degradation, and plays an important role in soil C stabilization by favoring humic substance formation through the catalysis of polyphenol oxidation reactions (Weand et al. 2010). Cellulase can break down cellulose to cellobiose, a sugar composed of two glucose units. Invertase catalyzes the hydrolysis of sucrose into glucose and fructose.

In this study, we compared effects of tree species after forest conversion based on a base line of undisturbed forest. Based on the analysis of different labile SOC fractions, soil respiration, and activities of six soil enzymes in four different subtropical forests, this study aimed to (1) examine the effect of forest conversion on labile SOC, soil respiration, and enzyme activity, (2) quantify the relationship among different labile SOC, soil respiration, and enzyme activity, and (3) determine whether labile SOC is a more sensitive indicator of soil quality than total SOC over the long term after forest conversion. We tested the following hypotheses: (1) that the conversion of a native broadleaved forest into a plantation decreases labile SOC, soil respiration, and enzyme activity, (2) that the soil MBC has a higher correlation with soil respiration and enzyme activity than the other SOC fractions, and (3) that labile SOC is a more sensitive indicator of soil quality than total SOC over the long term after forest conversion.

\section{Materials and methods}

\subsection{Study area}

The study was conducted at the Huitong National Research Station of Forest Ecosystem (26 $\left.50^{\prime} \mathrm{N}, 109^{\circ} 36^{\prime} \mathrm{E}\right)$. This region belongs to the transition zone from the Yun-Gui plateau to the lower mountains and hills along the southern bank of the Yangtze River. The altitude ranges from $300 \mathrm{~m}$ to $1,000 \mathrm{~m}$ above sea level. With a relatively deeper layer, red earth or reddish-yellow earth are generally distributed from $300 \mathrm{~m}$ to $600 \mathrm{~m}$ above sea level. This region has a humid mid-subtropical monsoon climate, with a mean annual temperature and precipitation of $16.5^{\circ} \mathrm{C}$ and $1,200 \mathrm{~mm}$ respectively. The native vegetation is evergreen broadleaved forest typical of subtropics, with Castanopsis fargesii Franch. and Quercus lotungensis Chun as the dominant species. The region is a major production area because of the rich water and heat resources. Therefore, many highly productive commercial tree species (e.g., Cunninghamia 
lanceolata Hook. and Pinus massoniana Lamb.) are planted after native forest clearcutting.

In the 1980s, most native evergreen broadleaved forests were cut and replaced by plantations. In the current study, we selected Cunninghamia lanceolata Hook. plantation, P. massoniana Lamb. plantation, and Michelia macclurei Dandy plantation forests established in 1984, 1987, and 1983 respectively, and an native broadleaf forestundisturbed for 50 years, representing four forest-use types. Three plots (i.e., three replications) of $20 \mathrm{~m} \times 20 \mathrm{~m}$ in each forest type were randomly established. The distance between the plots in each site is about $80 \mathrm{~m}$ to $100 \mathrm{~m}$. In each plot, trees with heights more than $1.3 \mathrm{~m}$ and diameters at breast height (DBHs) more than $1.5 \mathrm{~cm}$ were investigated. The dominant tree species in the native broadleaf forest were Castanopsis fargesii Franch., Q. lotungensis Chun, Machilus pauhoi Kaneh., Meliosma rigida Siebold, and Eurya nitida Korthals. In the NBF plots, the highest values of tree height and DBH were $30 \mathrm{~m}$ and $110 \mathrm{~cm}$ respectively. The soil was classified as an oxisol based on the US soil taxonomy (Soil Survey Staff 1999). Detailed information about the structural characteristics of the five forests and main soil physicochemical properties at investigation are shown in Table 1. The background values including soil profile characteristics, textures, and mineral composition were almost identical in the different plots (Chen et al. 2000). Consequently, any observed differences in soil properties among the forests are probably mainly due to management.

\subsection{Soil sampling and analysis}

To examine effects of forest conversion on labile SOC pools and microbial activity in mineral soil layer, the litter and organic horizon was removed, and six soil cores (diameter
$45 \mathrm{~mm}$ ) in each plot were collected in July 2011 from the upper $20 \mathrm{~cm}$ soil layer to pool into a composite soil sample. All soil samples were immediately sieved through a $2-\mathrm{mm}$ mesh. Some of the soil samples were stored at $3{ }^{\circ} \mathrm{C}$ for determining soil MBC, DOC, basal respiration, and enzyme activities within 7 days. The other samples were then dried for determining soil physicochemical properties and POC.

Soil MBC was measured through the chloroform fumigation- $\mathrm{K}_{2} \mathrm{SO}_{4}$ extraction method described by Vance et al. (1987). The fumigated and unfumigated soils were extracted using $0.5 \mathrm{~mol}^{-1} \mathrm{~K}_{2} \mathrm{SO}_{4}$ with a ratio of $1: 4$ (soil: $\mathrm{K}_{2} \mathrm{SO}_{4}$, w:v). The extracted $\mathrm{C}$ was measured using an elemental analyzer (Elementar High TOC, Germany). Soil MBC was calculated using a factor of 2.2. Soil basal respiration was determined using the method of alkali absorption. Briefly, the field-moist soils (50 g, oven-dry weight) were aerobically incubated at $28{ }^{\circ} \mathrm{C}$ in a $500 \mathrm{ml}$ sealed glass jar for $24 \mathrm{~h}$. The $\mathrm{CO}_{2}$ that evolved from the soil was trapped in $0.1 \mathrm{~mol} \cdot \mathrm{L}^{-1} \mathrm{NaOH}$ solution. The $\mathrm{NaOH}$ solution was then extracted for precipitation processing using a saturated $\mathrm{BaCl}_{2}$ solution. The amount of $\mathrm{CO}_{2}$ absorbed was determined by titration using $0.05 \mathrm{~mol} \cdot \mathrm{l}^{-1} \mathrm{HCl}$ solution and phenolphthalein as a visual indicator. The microbial metabolic quotient $\left(q \mathrm{CO}_{2}\right)$ was calculated by dividing the hourly basal respiration rate by the corresponding MBC.

POC encompasses all the organic components that can be readily oxidized by $\mathrm{KMnO}_{4}$, including labile humic material and polysaccharides (Conteh et al. 1999). POC is defined as the organic $\mathrm{C}$ oxidized by $0.333 \mathrm{~mol} \cdot \mathrm{l}^{-1} \mathrm{KMnO}_{4}$. $\mathrm{POC}$ was determined using the method recommended by Blair et al. (1995). Briefly, $100 \mathrm{mg}$ of soil sample was added into 50-ml plastic screw cap centrifuge tubes, followed by $25 \mathrm{ml}$ of $333 \mathrm{mmol} \cdot \mathrm{l}^{-1} \mathrm{KMnO}_{4}$. The centrifuge tubes were tightly sealed and shaken for $1 \mathrm{~h}$. The tubes were then centrifuged
Table 1 Structural characteristics of the four forests studied, and main soil physicochemical properties in subtropical China

NBF, CLP, PMP, and MMP denote an undisturbed native broadleaf forest, Cunninghamia lanceolata Hook. plantation, Pinus Massoniana Lamb. plantation, and Michelia macclurei Dandy plantation, respectively.

\begin{tabular}{|c|c|c|c|c|}
\hline Slope aspect & $\begin{array}{l}\text { NBF } \\
\text { NE }\end{array}$ & $\begin{array}{l}\text { CLP } \\
\text { NW }\end{array}$ & $\begin{array}{l}\text { PMP } \\
\text { NW }\end{array}$ & $\begin{array}{l}\text { MMP } \\
\text { SE }\end{array}$ \\
\hline Mean tree height $(\mathrm{m})$ & 9.00 & 17.9 & 19.1 & 17.4 \\
\hline Mean DBH $(\mathrm{cm})$ & 13.9 & 22.1 & 14.3 & 16.1 \\
\hline Stem density (no. $\cdot \mathrm{ha}^{-1}$ ) & 1500 & 1080 & 2100 & 1890 \\
\hline Mean soil water content $(\%)$ & 22.9 & 33.7 & 23.8 & 33.4 \\
\hline Soil total $\mathrm{N}\left(\mathrm{g} \cdot \mathrm{kg}^{-1}\right)$ & 1.70 & 1.61 & 1.48 & 1.70 \\
\hline Soil total $\mathrm{P}\left(\mathrm{g} \cdot \mathrm{kg}^{-1}\right)$ & 0.23 & 0.26 & 0.24 & 0.27 \\
\hline Mineral $\mathrm{N}\left(\mathrm{mg} \cdot \mathrm{kg}^{-1}\right)$ & 9.39 & 14.52 & 8.13 & 10.89 \\
\hline Available P $\left(\mathrm{mg} \cdot \mathrm{kg}^{-1}\right)$ & 1.07 & 1.17 & 1.14 & 1.35 \\
\hline Bulk density $\left(\mathrm{g} \cdot \mathrm{cm}^{-3}\right)$ & 1.18 & 1.23 & 1.25 & 1.08 \\
\hline $\mathrm{pH}\left(\mathrm{H}_{2} \mathrm{O}\right)$ & 4.43 & 4.32 & 4.30 & 4.38 \\
\hline Sand $(\%)$ & 6.9 & 11.4 & 12.2 & 11.2 \\
\hline Clay $(\%)$ & 43.5 & 47.6 & 43.6 & 38.2 \\
\hline Silt (\%) & 49.6 & 41.0 & 44.2 & 50.6 \\
\hline
\end{tabular}


for $5 \mathrm{~min}$ at 2,000 rpm, and the supernatants were diluted with deionized water. The absorbances of the diluted samples and standards were measured using an atomic absorption spectrophotometer (Varian AA240, America) at $565 \mathrm{~nm}$.

DOC was extracted with distilled water using the method described by Liang et al. (1998). Briefly, $10 \mathrm{~g}$ of fresh soil and $25 \mathrm{ml}$ of ultra-pure water were added into a centrifuge tube. For extraction, the mixture was shaken for $30 \mathrm{~min}$ on a reciprocal shaker (Labnet Pro 30, America), and then centrifuged at $6,000 \mathrm{rpm}$ for $15 \mathrm{~min}$. The extract was filtered through a $0.45-\mu \mathrm{m}$ glass fiber filter. The $\mathrm{C}$ in the extract was measured using an elemental analyzer (Elementar High TOC, Germany).

Invertase activity was assessed as described by Guan (1986). Briefly, $5 \mathrm{~g}$ of soil was mixed with $15 \mathrm{ml}$ of $8 \%$ sucrose, $5 \mathrm{ml}$ phosphate buffer at $\mathrm{pH} 5.5$, and $0.1 \mathrm{ml}$ toluene. The mixture was incubated for $24 \mathrm{~h}$ at $37{ }^{\circ} \mathrm{C}$. The glucose released by the invertase reacted with 3,5-dinitrosalicylic acid and 3-amino-5-nitrosalicylic acid, and was then measured on an atomic absorption spectrophotometer (Varian AA240, America) at $508 \mathrm{~nm}$. The results were expressed as $\mathrm{mg}$ released glucose by $1 \mathrm{~g}$ soil per day. Soil urease activity was also determined using a standard colorimetric assay described by Guan (1986), and the results were expressed as $\mathrm{mg}$ of released $\mathrm{NH}_{3}-\mathrm{N}$ by $1 \mathrm{~kg}$ of soil per hour at $37^{\circ} \mathrm{C}$.

Cellulase activity was assessed using the modified method of Deng and Tabatabai (1994). Briefly, $5 \mathrm{~g}$ of soil sample was mixed with $20 \mathrm{ml}$ of $50 \mathrm{mmol} \cdot \mathrm{l}^{-1}$ acetate buffer with pH 5.5 and $2 \%$ of carboxymethyl cellulose. The mixture was incubated for $4 \mathrm{~h}$ at $50{ }^{\circ} \mathrm{C}$ and then centrifuged. The supernatant was treated with the Somogyi-Nelson reagent. Ammonium molybdate $(25 \mathrm{mg}$ ) was dissolved in $450 \mathrm{ml}$ of distilled water. Then, $21 \mathrm{ml}$ of concentrated $\mathrm{H}_{2} \mathrm{SO}_{4}$ was mixed into the solution. $\mathrm{Na}_{2} \mathrm{HASO}_{4} \cdot 7 \mathrm{H}_{2} \mathrm{O}(3 \mathrm{mg})$ was dissolved in $25 \mathrm{ml}$ of $\mathrm{H}_{2} \mathrm{O}$ and mixed. The solution was centrifuged once as described above, before the color measurement of reducing sugars at $520 \mathrm{~nm}$.

Acid phosphatase activity was determined using the method described by $\mathrm{Wu}$ et al. (2006). Briefly, $10 \mathrm{ml}$ of di-sodiumphenyl phosphate solution $\left(25 \mathrm{~g} \cdot \mathrm{l}^{-1}\right)$ used as a substrate was added to $5 \mathrm{~g}$ of soil. Soil samples were incubated for $12 \mathrm{~h}$ at $37{ }^{\circ} \mathrm{C}$ in acetate buffer $(\mathrm{pH} 5.0)$. The buffer solution $(5 \mathrm{ml})$ and filtrate $(2 \mathrm{ml})$ were transferred into a $50 \mathrm{ml}$ volumetric flask, and then diluted with distilled water to $25 \mathrm{ml}$. Subsequently, $0.5 \mathrm{ml}$ of 2,6-dibromoquinonechlorimide solution was added to the flask, which was incubated for $20 \mathrm{~min}$ at room temperature. Finally, we diluted the solution to $50 \mathrm{ml}$, and determined the released phenol at $600 \mathrm{~nm}$ on an atomic absorption spectrophotometer (Varian AA240, America). Acid phosphatase activity was expressed as mg hydrolyzed phenol by $1 \mathrm{~kg}$ soil per hour at $37^{\circ} \mathrm{C}$.

Catalase activity was determined according to the method of Guan (1986). Briefly, $2 \mathrm{~g}$ of soil with $40 \mathrm{ml}$ distilled water and $5 \mathrm{ml} 0.3 \% \mathrm{H}_{2} \mathrm{O}_{2}$ were added into centrifuge tubes, and then shaken for $20 \mathrm{~min}$. The filtrate was titrated with $25 \mathrm{mmol} \cdot \mathrm{l}^{-1} \mathrm{KMnO}_{4}$. The results were expressed as $\mathrm{ml}$ $25 \mathrm{mmol} \cdot 1^{-1} \mathrm{KMnO}_{4} \cdot \mathrm{g}^{-1} \cdot \mathrm{h}^{-1}$.

Polyphenol oxidase activity was determined using the method described by Guan (1986). Soil samples (5 g) were mixed with $10 \mathrm{ml}$ of distilled water, $6 \mathrm{ml}$ of $0.1 \%$ ascorbic acid, and $10 \mathrm{ml}$ of $0.02 \mathrm{~mol} \cdot \mathrm{l}^{-1}$ catechol, and then incubated for $2 \mathrm{~min}$ in a water bath at $30{ }^{\circ} \mathrm{C}$. We then added $3 \mathrm{ml}$ of $10 \%$ phosphoric acid. The filtrate was titrated with $0.005 \mathrm{~mol} \cdot \mathrm{l}^{-1}$ iodine. The results were expressed as $\mathrm{ml}$ $0.005 \mathrm{~mol} \cdot \mathrm{l}^{-1} \mathrm{I}_{2} \cdot \mathrm{g}^{-1} \cdot \mathrm{h}^{-1}$.

\subsection{Statistical analyses}

The effects of land use on the labile SOC fractions, soil respiration, and enzyme activities were tested via one-way analysis of variance (ANOVA) using the SPSS software version 17.0 for Windows (SPSS Inc., Chicago, IL, USA). Assumptions of normality and homogeneity of variances were checked, and dependent variables were natural log transformed where necessary. Tukey's honestly significant difference test was performed as a post-hoc test to separate the means when differences were significant. The relationships between the SOC fractions and soil respiration, as well as soil enzyme activity, were modeled via the Pearson linear procedure using the SPSS software. Pearson linear correlations were also analysed to assess the relationships between the labile SOC fractions and soil enzyme activity. All effects were considered significant at the $P<0.05$ level.

\section{Results}

\subsection{SOC fractions}

Forest conversion from native broadleaf forest to plantation significantly affected soil MBC (Fig. 1). Significant differences in soil MBC were observed only between native broadleaf forest and Michelia macclurei Dandy plantation. Soil MBC in M. macclurei Dandy plantation was $45.9 \%$ higher than that in native broadleaf forest. However, total SOC, DOC, and POC were not significantly affected by forest conversion. Forest conversion significantly affected the ratios of labile SOC fractions to total SOC. The ratio of soil MBC to total SOC was $27.6 \%$ higher in $M$. macclurei Dandy plantation than in native broadleaf forest. Forest conversion from native broadleaf forest to $C$. lanceolata Hook. plantation decreased the ratio of DOC to total SOC, and the conversion from native broadleaf forest into $P$. massoniana Lamb. plantation decreased the ratio of DOC to total SOC. The labile SOC fractions were significantly correlated with total SOC, but POC had the highest correlation (Fig. 2). 
Fig. 1 Changes in total soil organic $\mathrm{C}$, microbial biomass $\mathrm{C}$ $(M B C)$, dissolved organic $\mathrm{C}$ $(D O C)$, and permanganateoxidizable $\mathrm{C}(P O C)$, as well as ratios of $\mathrm{MBC}, \mathrm{DOC}$, and $\mathrm{POC}$ to total SOC in the four subtropical forests. $N B F, C L P$, $P M P$, and $M M P$ denote an undisturbed native broadleaved forest, Cunninghamia lanceolata Hook. plantation, Pinus massoniana Lamb. plantation, and Michelia macclurei Dandy plantation, respectively. Different letters on the bar denote significance at $P<0.05$
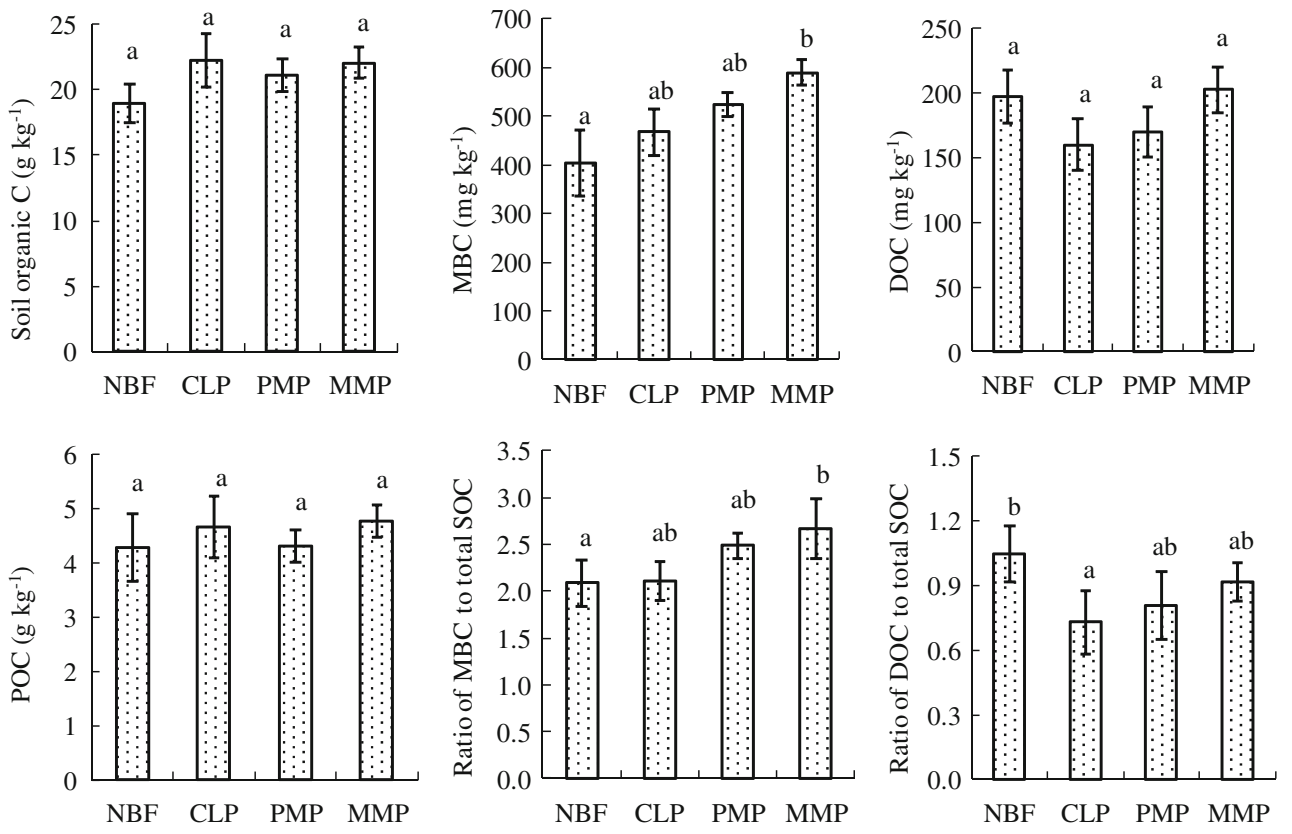

\subsection{Soil respiration and enzyme activity}

Soil respiration increased by $25.2 \%$ and $21.7 \%$ after conversion from native broadleaf forest to $P$. massoniana Lamb. plantation and M. macclurei Dandy plantation respectively (Fig. 3). Forest conversion tended to reduce the $q \mathrm{CO}_{2}$, but not significantly. Soil basal respiration and labile SOC fractions had comparatively stronger relationships (Fig. 4). However, the relationship between soil basal respiration and total SOC was weaker.

Forest conversion significantly affected soil enzyme activities (Fig. 5), but the response patterns of the soil enzyme activities differed. Conversion from native broadleaf forest to plantations increased the invertase and polyphenol oxidase activities, but decreased the cellulase activity. Urease activity increased after conversion from native broadleaf forest to $M$. macclurei Dandy plantation, but the catalase activity decreased. Conversion from native broadleaf forest to P. massoniana Lamb. plantation decreased the acid phosphatase activity.

\subsection{Relationship between soil enzyme activities and SOC fractions}

The soil enzyme activities had inconsistent relationships with the labile SOC fractions (Table 2). Total SOC and
Fig. 2 Relationship of labile SOC fractions [microbial biomass $\mathrm{C}(M B C)$, dissolved organic $\mathrm{C}(D O C)$, and permanganate-oxidizable $\mathrm{C}$ $(P O C)]$ with total SOC in the subtropical forests. * and $* *$ denote significance at $P<0.05$ and 0.01 respectively

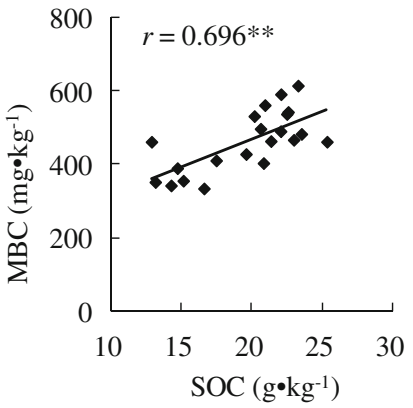

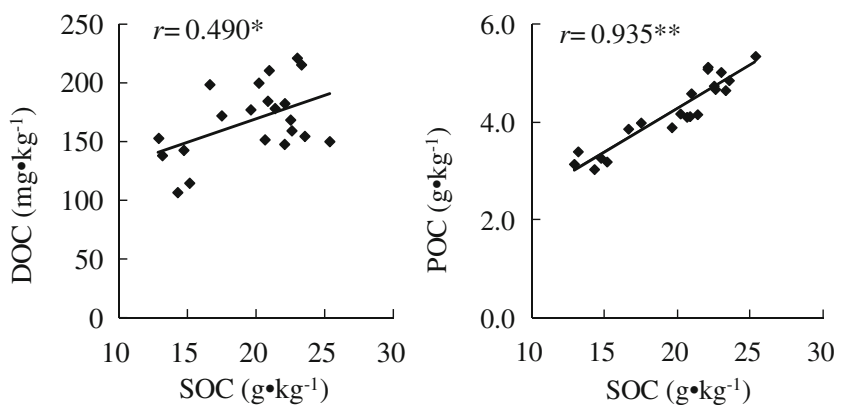


Fig. 3 Soil basal respiration and microbial metabolic quotient in the four subtropical forests. $N B F, C L P, P M P$, and $M M P$ denote an undisturbed native broadleaved forest, $C$. lanceolata Hook. plantation, $P$. Massoniana Lamb. plantation, and M. macclurei Dandy plantation, respectively. Different letters on the bar denote significance at $P<0.05$
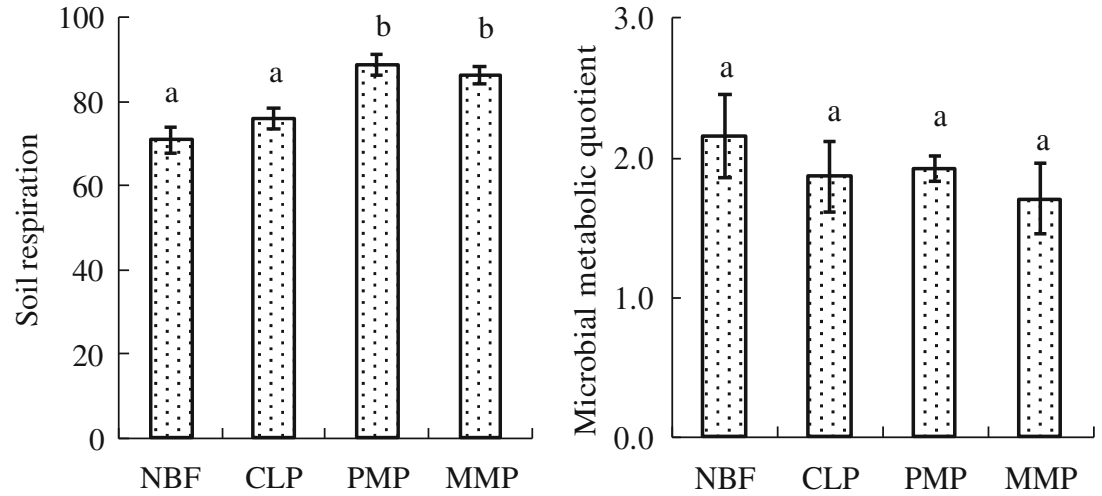

POC were not correlated with any soil enzyme activity. MBC was positively correlated with the urease activity and negatively correlated with the cellulase activity. DOC was positively correlated with urease and acid phosphatase activities.

\section{Discussion}

In contrast to our first hypothesis, we found that forest conversion from native broadleaf forest to plantation affected only the soil MBC but not the other labile SOC fractions. Our results were supported by other previous studies (Wang and Wang 2007; Xu et al. 2008). These results indicate that the response of labile SOC fractions to forest conversion depends on forest vegetation. Litter and root are the primary source of SOC. Therefore, the different quantities and qualities of organic matter input through litterfall and root activity (e.g., turnover and exudates) induced by the different tree species were responsible for the different responses of labile SOC to forest conversion (Wang and Wang 2007; Vesterdal et al. 2008). This finding was supported by the observations of Wang et al. (2007) in similar regions, which showed that tree species affect litter production and dynamics. The significant increase in soil MBC induced by forest conversion is important for $\mathrm{C}$ emission and storage in soil. Soil microbial activity utilizes $\mathrm{SOC}$ as $\mathrm{C}$ source and releases $\mathrm{CO}_{2}$ to atmosphere, which increases the $\mathrm{C}$ emission from soil to atmosphere and reduces soil $\mathrm{C}$ storage. The higher soil respiration in plantations than in NBF also supported our hypotheses, although total SOC had no significant change.

Unexpectedly, the soil enzyme activities showed different patterns of response to forest conversion. Hou et al. (2006) also found that urease and catalase activities differed among
Fig. 4 Relationship of soil basal respiration $\left(\mathrm{mg} \mathrm{CO} \mathrm{Cg}^{-1}\right.$ dry soil $\left.\cdot \mathrm{d}^{-1}\right)$ with total soil organic $\mathrm{C}\left(\mathrm{SOC} ; \mathrm{g} \cdot \mathrm{kg}^{-1}\right)$, microbial biomass $\mathrm{C}(M B C$; $\left.\mathrm{mg} \cdot \mathrm{kg}^{-1}\right)$, dissolved organic $\mathrm{C}$ (DOC; $\mathrm{mg} \cdot \mathrm{kg}^{-1}$ ) and permanganate-oxidizable $\mathrm{C}$ $\left(P O C ; \mathrm{g} \cdot \mathrm{kg}^{-1}\right)$ in the subtropical forests. $*$ denotes significance at $P<0.05$
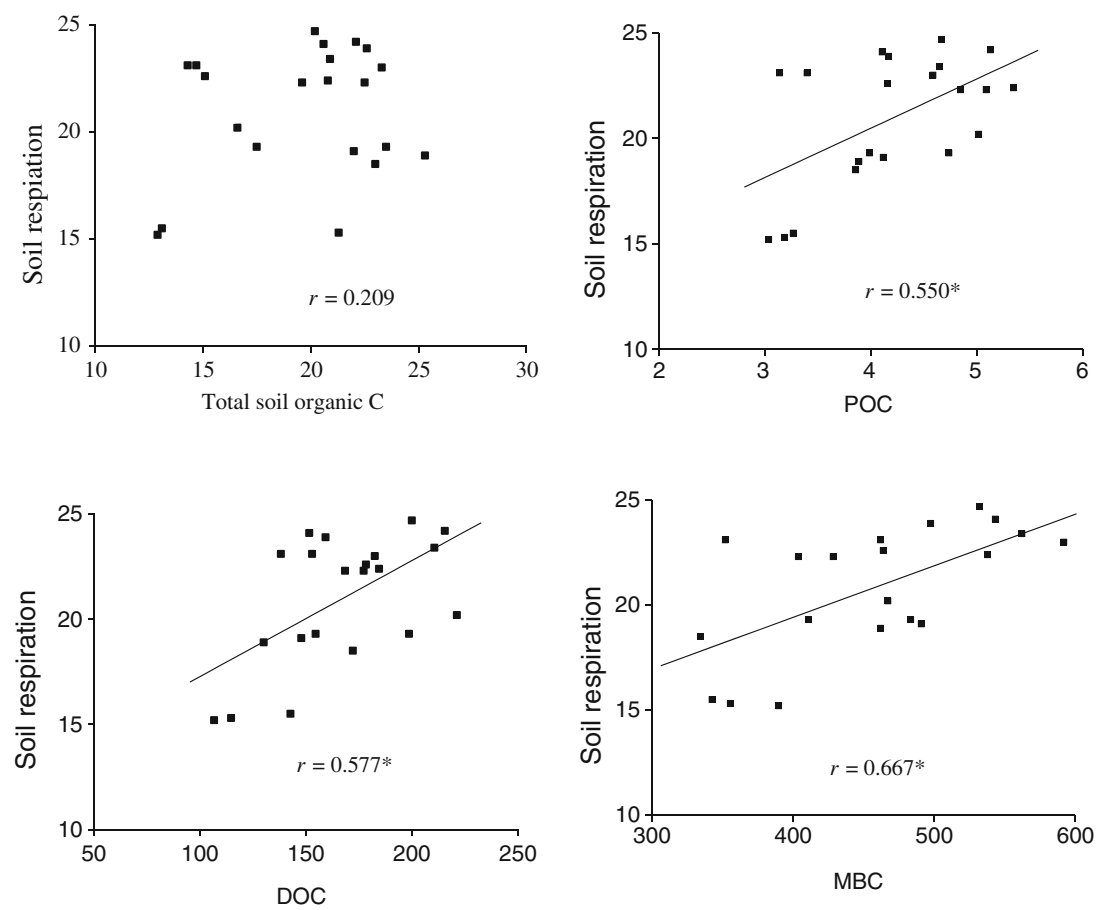
Fig. 5 Activities of soil invertase (mg released glucose $\cdot \mathrm{kg}^{-1}$ soil $\left.\cdot \mathrm{d}^{-1}\right)$, cellulase (mg reducing sugar $\mathrm{kg}^{-1}$ soil $\left.h^{-1}\right)$, urease (mg released $\mathrm{NH}_{3}-\mathrm{N} \cdot \mathrm{kg}^{-1}$ soil $\cdot \mathrm{h}^{-1}$ ), catalase (ml $25 \mathrm{~mol}^{-1} \mathrm{KMnO}_{4} \cdot \mathrm{kg}^{-1}$ soil $\cdot \mathrm{h}^{-1}$ ), acid phosphatase (mg hydrolyzed phenol $\cdot \mathrm{kg}^{-1}$ soil $\left.\cdot \mathrm{h}^{-1}\right)$, and polyphenol oxidase ( $\mathrm{ml} 0.05 \mathrm{~mol}^{-1} \mathrm{I}_{2} \cdot \mathrm{kg}^{-1}$ soil $\mathrm{h}^{-1}$ ) in the four subtropical forests. $N B F, C L P, P M P$, and $M M P$ denote an undisturbed native broadleaved forest, $C$. lanceolata Hook. plantation, $P$. massoniana Lamb. plantation, and M. macclurei Dandy plantation, respectively. Different letters on the bar denote significance at $P<0.05$
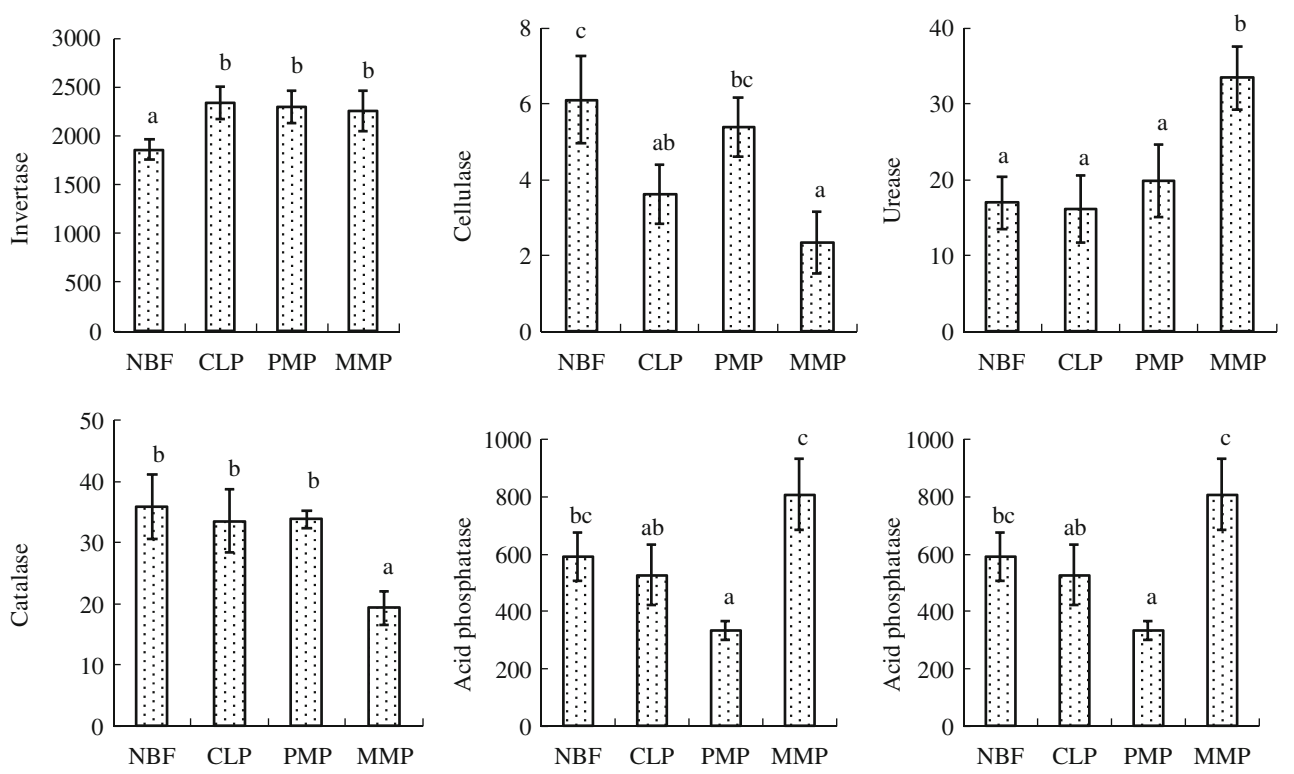

three forest types in Yellow River Delta. The increase in invertase activity after forest conversion indicates that the microbial activity and $\mathrm{C}$ availability increased (Wallenstein et al. 2009), which was supported by the increase in soil $\mathrm{MBC}$ and respiration. Given the key roles of PPO in soil carbon stabilization, the significant increase in PPO activity suggests that forest conversion increased the soil C stability. Waldrop et al. (2004) found that PPO activity decreases with increasing mineral $\mathrm{N}$ availability. Therefore, the relatively lower mineral $\mathrm{N}$ and total $\mathrm{N}$ in soils from $P$. massoniana Lamb. plantation was partly responsible for the higher PPO activity. The different patterns of soil enzyme activities in the plantations suggest that soil enzymes have tree speciesspecific response to forest conversion.

In a subtropical montane forest with limited $\mathrm{P}$, microbial $\mathrm{P}$ mineralization is essential for supplying trees with available P. Acid phosphatase had different responses after forest conversion based on the tree species, which is consistent with the observations of Ushio et al. (2010) in a tropical montane forest. Phosphatase activity is correlated with the available P concentration (Acosta-Martínez et al. 2007), and is suppressed by $\mathrm{P}$ addition (Allison and Vitousek 2005). Therefore, the differences in acid phosphatase activity under different forests may be due to the differences in soil available $\mathrm{P}$ induced by different tree species.

Some of the enzyme activities were correlated with the labile SOC fractions, which confirms some previous studies (Brzezińska et al. 2005; Acosta-Martínez et al. 2007). However, Shackle et al. (2000) reported that phosphatase activity is not regulated by $\mathrm{C}$ availability in constructed wetlands. Generally, enzyme activities are correlated with SOC content because the latter plays a key role as a precursor for enzyme synthesis. The significant inter-correlation among cellulase, urease, catalase, and acid phosphatase activities (data not shown) suggests that these enzymes have similar origin and $\mathrm{C}$ source in soil. The higher correlation between the soil enzyme activities and MBC than SOC and POC also suggests that soil enzyme activity was partly controlled by soil C availability. Significant relationships between soil respiration and labile SOC fraction were also found, which is in accordance with some studies (Dube et al. 2009; Iqbal et al. 2010). In addition, soil respiration was highly related to MBC. The aforementioned results confirm our hypothesis that the soil MBC has higher correlation with soil respiration and enzyme activity than the other SOC fractions.

Table 2 Pearson product-moment correlation coefficients between soil enzymes and SOC fractions in the four subtropical forests

\begin{tabular}{llllllr}
\hline & Invertase & Cellulase & Urease & Catalase & Acid phosphatase & Polyphenol oxidase \\
\hline SOC & 0.371 & -0.417 & 0.080 & -0.035 & -0.219 & 0.019 \\
MBC & 0.279 & $-0.515^{*}$ & $0.626^{*}$ & $-0.613^{*}$ & 0.170 & 0.344 \\
DOC & -0.188 & -0.085 & $0.697^{*}$ & -0.421 & $0.524^{*}$ & -0.176 \\
POC & 0.263 & -0.305 & 0.022 & 0.025 & -0.094 & -0.243
\end{tabular}

SOC, MBC, DOC, and POC denote total soil organic C, microbial biomass $\mathrm{C}$, dissolved organic $\mathrm{C}$, and permanganate-oxidizable $\mathrm{C}$ respectively. $*$ denotes significance at $P<0.05$ 
Total SOC was insignificantly changed 30 years after forest conversion. However, significant correlations between SOC and labile fractions were found, which confirms the previous results of Wang et al. (2007) in a similar study region. The higher correlation between POC and total SOC suggests that POC is more closely related to the amount of total SOC, accounting for $21.5 \%$ of total SOC. The POC fraction accounts for $5 \%$ to $30 \%$ of total SOC (Blair et al. 1995; Conteh et al. 1999). Therefore, the amount of labile SOC was controlled by the amount of total SOC in long-term scales after forest conversion. In contrast to our hypothesis, the aforementioned results indicate that measuring the more laborious labile forms with the exception of MBC provides little additional value. Furthermore, $\mathrm{MBC}$ is a sensitive indicator of soil quality over the long term after land-use changes compared with other SOC fractions, although soil quality is a complex concept, and its determination is the result of assessing several biological, chemical, and physical soil components.

In conclusion, forest conversion from native broadleaf forest to monoculture plantations increased only the MBC but not the other labile fractions and total SOC. As expected, the soil MBC had higher correlation with soil respiration and enzyme activity than the other SOC fractions. Soil C availability partly controlled the microbial and enzyme activities. MBC was a more sensitive indicator of soil quality compared with total SOC over the long term after forest conversion. Changes in soil biodiversity and its consequence on the organisms under the trees in monoculture plantations should be further studied. On the other hand, monitoring abiotic changes also should be implemented.

Acknowledgments We are grateful to Micai Zhong, Guangbiao Xu, Xiuyong Zhang, and Zhengqi Shen for their assistance during soil sampling and analysis.

Funding This research was supported by the National Basic Research Program of China (973 Program, 2012CB416905), the "Strategic Priority Research Program-Climate Change: Carbon Budget and Related Issues" of the Chinese Academy of Sciences (XDA05070305), and the National Natural Science Foundation of China (31070436 and 41030533).

\section{References}

Acosta-Martínez V, Cruz L, Sotomayor-Ramírez D, Pérez-Alegría L (2007) Enzyme activities as affected by soil properties and land use in a tropical watershed. Appl Soil Ecol 35:35-45

Allison SD, Vitousek PM (2005) Response of extracellular enzymes to simple and complex nutrient inputs. Soil Biol Biochem 37:937-944

Blair GJ, Lefroy RDB, Lisle L (1995) Soil carbon fractions based on their degree of oxidation and the development of a carbon management index for a cultural systems. Aust J Agric Res 46:1459-1466

Brzezińska M, Włodarczyk T, Stepniewski W, Przywara G (2005) Soil aeration status and catalase activity. Acta Agrophysica 5:555-565
Chang E, Chen C, Chen T, Chiu C (2011) Soil microbial communities and activities in sand dunes of subtropical coastal forests. Appl Soil Ecol 49:256-262

Chen CY, Liao LP, Wang SL (2000) Ecology of Chinese Fir plantation forest. Science Press, Beijing, pp 1-39, 84-96 (in Chinese)

Cochran RL, Collins HP, Kennedy A, Bezdicek DF (2007) Soil carbon pools and fluxes after land conversion in a semiarid shrub-steppe ecosystem. Biol Fertil Soils 43:479-489

Conteh A, Blair GT, Lefroy RDB, Whitbread AM (1999) Labile organic carbon determined by permanganate oxidation and its relationships to other measurements of soil organic carbon. Hum Substit Environ J 1:3-15

Deng SP, Tabatabai MA (1994) Cellulase activity of soils. Soil Biol Biochem 26:1347-1354

Dilly O, Nannipieri P (2001) Response of ATP content, respiration rate and enzyme activities in an arable and a forest soil to nutrient addition. Biol Fertil Soils 34:64-72

Dube F, Zagal E, Stolpe N, Espinosa M (2009) The influence of land-use change on the organic carbon distribution and microbial respiration in a volcanic soil of the Chilean Patagonia. Forest Ecol Manag 257:1695-1704

Food and Agriculture Organization of the United Nations (2010) Global forest resources assessment 2010: main report. FAO Viale delle Terme di Caracalla, Rome

Guan S (1986) Soil enzymes and their methodology. Agricultural Press, Beijing, pp 274-340

Hou B, Ma F, Song Y, Hou L, Cui X (2006) A study on effect of different tree species on soil nutrients, enzyme activities and microorganisms. Acta Agric Univ Jiangxiensis 28:734-738

Iqbal J, Hu R, Feng M, Lin S, Malghani S, Ali IM (2010) Microbial biomass, and dissolved organic carbon and nitrogen strongly affect soil respiration in different land uses: a case study at Three Gorges Reservoir Area, South China. Agric Ecosyst Environ 137:294-307

Liang BC, MacKenzie AF, Schnitzer M, Monreat CM, Voroney PR, Beyaert RP (1998) Management-induced changes in labile soil organic matter under continuous corn in eastern Canadian soils. Biol Fertil Soils 26:88-94

Liu J, Jiang P, Wang H, Zhou G, Wu J, Yang F, Xi Q (2011) Seasonal soil $\mathrm{CO}_{2}$ efflux dynamics after land use change from a natural forest to Moso bamboo plantations in subtropical China. Forest Ecol Manag 262:1131-1137

Mohanty RB, Panda T (2011) Soil respiration and microbial population in a tropical deciduous forest soil of Orissa, India. Flora-Morphol Distrib Funct Ecol Plants 206:1040-1044

Rovira P, Vallejo VR (2002) Labile and recalcitrant pools of carbon and nitrogen in organic matter decomposing at different depth in soil: an acid hydrolysis approach. Geoderma 107:109-141

Schroth G, D'Angelo SA, Teixeira WG, Haag D, Lieberei R (2002) Conversion of secondary forest into agroforestry and monoculture plantations in Amazonia: consequences for biomass, litter and soil carbon stocks after 7 years. Forest Ecol Manag 163:131-150

Shackle VJ, Freeman C, Reynolds B (2000) Carbon supply and the regulation of enzyme activity in constructed wetlands. Soil Biol Biochem 32:1935-1940

Sicardi M, García-Préchac F, Frioni L (2004) Soil microbial indicators sensitive to land use conversion from pastures to commercial Eucalyptus grandis (Hill ex Maiden) plantations in Uruguay. Appl Soil Ecol 27:125-133

Soil Survey Staff (1999) Soil taxonomy: a basic system of soil classification for making and interpreting soil surveys. United States Department of Agriculture. Soil Conservation Service. U.S. Government Printing Office, Washington, DC

Ushio M, Kitayama K, Balser TC (2010) Tree species effects on soil enzyme activities through effects on soil physicochemical and 
microbial properties in a tropical montane forest on Mt. Kinabalu, Borneo. Pedobiologia 53:227-233

Vance ED, Brookes PC, Jenkinson DS (1987) An extraction method for measuring soil microbial biomass C. Soil Biol Biochem 19:703-707

Vesterdal L, Schmidt IK, Callesen I, Nilsson LO, Gundersen P (2008) Carbon and nitrogen in forest floor and mineral soil under six common European tree species. Forest Ecol Manag 255:35-48

von Lützow M, Kögel-Knabner I, Ekschmitt K, Flessa H, Guggenberger G, Matzner E, Marschner B (2007) SOM fractionation methods: relevance to functional pools and to stabilization mechanisms. Soil Biol Biochem 39:2183-2207

Waldrop MP, Zak DR, Sinsabaugh RL, Gallo M, Lauber C (2004) Nitrogen deposition modifies soil carbon storage through changes in microbial enzymatic activity. Ecol Appl 14:1172-1177

Wallenstein MD, Mcmahon SK, Schimel JP (2009) Seasonal variation in enzyme activities and temperature sensitivities in Arctic tundra soils. Glob Chang Biol 15:1631-1639
Wang Q, Wang S (2007) Soil organic matter under different forest types in southern China. Geoderma 142:349-356

Wang Q, Wang S, Fan B, Yu X (2007) Litter production, leaf litter decomposition and nutrient return in Cunninghamia lanceolata plantations in south China: effect of planting conifers with broadleaved species. Plant Soil 297:201-211

Weand MP, Arthur MA, Lovett GM, McCulley RL, Weathers KC (2010) Effects of tree species and $\mathrm{N}$ additions on forest floor microbial communities and extracellular enzyme activities. Soil Biol Biochem 42:2161-2173

Wu J, Lin Q, Huang Q, Xiao H (2006) Soil microbial biomass - methods and application. China Meteorological Press, Beijing, pp 127-129

Xu Z, Ward S, Chen C, Blumfield T, Prasolova N (2008) Soil carbon and nutrient pools, microbial properties and gross nitrogen transformations in adjacent natural forest and hoop pine plantations of subtropical Australia. J Soil Sediment 8:99-105 